\title{
Community and conservation in Wallacea: Making the case for the region, a methodological framework, and research trends
}

\author{
Micah R. Fisher ${ }^{1,2}$, Bart Verheijen ${ }^{1,3}$, Muhammad Alif K. Sahide ${ }^{{ }^{*}}$ \\ 1 Universitas Hasanuddin, Faculty of Forestry \\ 2 University of Hawaii, Affiliate Faculty - Matsunaga Institute for Peace and Conflict Resolution \\ 3 University of Amsterdam \\ * Corresponding author: muhammad.alif@unhas.ac.id
}

\begin{abstract}
This introduction provides a review of articles published in the special section on community conservation in the Wallacea region. As editors to the special section, we worked with contributors over a series of workshops to reflexively identify challenges to conducting research on community and conservation in this important and often overlooked region. The challenges are attributable to the dynamism and remoteness of the region, as well as its peripheral position relative to the center of government in Indonesia. We begin this article by making the case for a concerted field of study for the Wallacea region. Next, we draw on empirical research and continued engagement from across Wallacea to propose a framework that helps make better sense of the often perplexing trends involving communities and conservation in the region. We call the framework ASLi, which addresses the key institutions that negotiate conservation and development, including Adat and adaptive local institutions and the State. We situate these institutions within the dimensions of Livelihoods and their relations with natural resources. In testing out the framework with research groups and practitioners from across the region, we found that each of the aspects of the framework are fundamental for better understanding and facilitating policy discussions involving communities and conservation. In the second part of the article we shift our attention to assessing the empirical contributions from the special section. The empirical examples include eight articles from across the provinces of Sulawesi, East Nusa Tenggara, Maluku, and North Maluku. The issues range from topics that include: illegal species trade; human environment relations around charismatic species (e.g. komodocommunity relations); watersheds, lakes, and landscapes; ecotourism; policy analysis; conservation management and planning; and, community participation and collaborative governance. There is much that remains misunderstood and misinterpreted about the Wallacea region. This initial set of consolidated and rich empirical material, combined with an organizing framework for continuing to study these issues, charts new horizons for future research.
\end{abstract}

Keywords: ASLi framework; adat-state-livelihood; community-based conservation; Wallacea

\section{Introduction}

This special section consists of work by a research group with longstanding interest and engagement in communities and conservation in a unique and understudied region -- the Wallacea region. This dynamic and diverse region begins East of Borneo and stretches towards the blurred boundaries of Melanesia. The research also represents a commitment to bottom up perspectives. Each author has an important story to tell about local communities, their relationship to the state, and their connection to natural resources.

All the empirical cases in this special section share a similarity of strong local engagement. Some contributions approach research by building conclusions from close participant observation that allow findings to emerge from detailed empirical descriptions. Others brought a careful theoretical lens to structure their approach. Nonetheless, from our work with local researchers, we began to question whether there was perhaps a more strategic way to frame issues of community conservation taking place in the Wallacea Region. 
The aim of the introduction to this special section is twofold. The first is to help researchers and practitioners make sense of research in and about the region while also building capacity and providing greater exposure on the importance of conducting research in Wallacea. Meeting the needs identified by the numerous field researchers and practitioners we interacted with for this special section, this introduction article presents a framework for approaching research in the Wallacea region and making better sense of the complex issues related to community and conservation. We present a common heuristic to help make sense of the complexity of the region, which is intended to honor local voices and perspectives, empower local researchers and organizations, and broaden possibilities for navigating the often contradictory trends taking place across Wallacea. We call the three-part framework "ASLi," and it consists of the following pillars: i) Adat and adaptive local institutions (a convergence of both the longstanding and emergent cultural dimensions); ii) the State (the various levels of formal institutions); and, iii) Livelihoods (the ways people make a living and define their lives). Though the framework is not all-encompassing, overlooking any of its constituent pillars will result in missing important aspects of community conservation in the region.

Second, we set out to ask: what are some of the broader dynamics on community conservation unfolding in the Wallacea region? How are the findings unique to the region? By comparing across eight articles conducted at different governing scales, we highlight some of the emerging trends regarding community conservation in the region. Between the two objectives of the paper, we hope that the framework and empirical discoveries helps to establish a coarse baseline for others interested in natural resource dynamics, and the communities and institutions that negotiate them, in the complex Wallacea region. We close with potential pathways going forward. Before addressing these two larger aims of the paper however, we first make the case for why a concerted research agenda for the Wallacea region is necessary and so timely.

\section{The Wallacea region? Making the case for a research agenda}

The Wallacea region identifies ocean and islands that border the division between the Asian and Australian continental shelves. Within the Wallacea region, large islands and groupings of islands begin in the west with Sulawesi, spread East through the Malukus, and Southeast towards the Lesser Sundas (Nusa Tenggara). Wallacea has the highest concentration of islands in Indonesia, ${ }^{1}$ and has a larger land area than the Philippines $\left(347,000 \mathrm{~km}^{2}\right)$. The population of the region amounts to over 31 million people, ${ }^{2}$ with numerous language classifications and diverse traditions.

The term Wallacea harks back to the naturalist Alfred Russel Wallace (1823-1913). Marked by a prehistoric past of connectivity and rupture, the islands that comprise Wallacea were shaped by geologic drifts and convergences between tectonic plates. Over time, distinct biodiversity evolved across these islands, notably different from organisms in Sundaland to the east, or Near Oceania to the west. Wallace's observations of species biodiversity and differentiation in this region, which he meticulously catalogued and sent back to the Royal Botanical Gardens in England, provided empirical evidence and theoretical foregrounding that helped shaped Darwin's theories of natural selection (Wallace, 1962). Today, Wallacea represents a region of high terrestrial biodiversity in addition to encompassing the center of the coral triangle, the most biodiverse marine region in the world.

\footnotetext{
${ }^{1}$ According to the Ministry of Home Affairs register for the provinces of Central Sulawesi, East Nusa Tenggara, Gorontalo, Maluku, North Maluku, North Sulawesi, South Sulawesi, Southeast Sulawesi, West Nusa Tenggara, there is a total of 7,452 islands (though excludes data from the more recently created West Sulawesi province)

${ }^{2}$ This is calculated on Central Bureau of Statistics Data, which includes: 17.36 million people for all the provinces on the island of Sulawesi; 5.07 million for NTT; 4.7 million for NTB; 1.7 million in Maluku; 1.14 million in North Maluku; and,1.2 million when adding in the split island state of East Timor at 1.2 million people.
} 
Historically, the Wallacea region was of great commercial interest to the East India Companies (EOCS) engaged in trade with influential local sultanates and kingdoms. The EOCs transitioned into colonial rule by the Dutch. Despite its economic and historical importance, throughout the 20th century the Wallacea region has been overlooked for the economic and political primacy of Java and the western regions of Indonesia (Wall et al., 1928; Ardhana, 2005). In contemporary Indonesia, the Wallacea region consists of ten provinces that span the largest of the islands (Sulawesi), and the archipelagos dispersed across the lesser Sundas and the Malukus. Pushed to the margins of development by the modern state, today these provinces are among the poorest (both per capita and total GDP) in Indonesia.

There is a lack of research on the Wallacea Region. Historical analyses of Wallacea often focus on the role of the region as a coveted trading post for lucrative commodities that shaped its colonial past, or are in the tradition of Wallace, focused on the unique biogeography, and quantity and dispersal of species types (Bini et al., 2006). Another area of research has focused on the cultural diversity of the region, but usually specific to the linguistic elements of fragmentation across numerous islands (Schapper, 2015). Finally, much less attention falls under the broader category of development studies, and although there is some established literature in public health such as genetics and disease, there is much less attention on poverty, policy, and political ecology (Resosudarmo and Jotzo, 2009).

Research in the Wallacea region typically separates cultural and environmental studies. We seek to bridge this division. Although classical research traditions on Wallacea reflect the unique role that the region played in the past, we establish a research agenda that promotes Wallacea for the role it can play in complementing contemporary theoretical and empirical research on naturesociety relations. Global studies of nature-society relationships provide important insights to establishing this agenda. Studies include those that examine top down conservation governance regimes (Lake, 2002; Tsing, 2005), the bottom up formulations of traditional and indigenous knowledge to elevate the role of communities in sustainably managing resources (Brosius et al., 1998; Berkes, 1999), co-management arrangements that incorporate both (Armitage et al., 2009), decentralized governance regimes that explicitly acknowledge the role of local authority (Ribot and Larson, 2013) and the more classical studies of the commons (Ostrom, 1990), as well as the land and power relations that determine resource access and exclusion (Schlager and Ostrom, 1992; Rose, 1994; Ribot and Peluso, 2003; Sikor and Lund, 2010; Hall et al., 2012). We thus seek to examine explicit political ecologies to promote better understanding of this vast understudied region (for more on political ecology, see Robbins, 2012).

Political ecology is concerned with the relations of people and the environment, how power and resources are shaped and reflexively interact, who benefits, and what ecologies emerge as a result. Drawing on political ecology, we seek to pose and answer questions about how, and under what conditions, resource exploitation or conservation occurs. For example, In what ways are communities in the Wallacea region not just utilizing, but also protecting its precious resources, and how do these dynamics interact with livelihoods and local identities? What type of institutions underpin such arrangements, and what can we learn by comparing these diverse ecologies and customs? As we will show in the empirical material from this special section, the answer is almost never clear or uniform. Sometimes, even neighboring communities can exhibit some perplexing and contradictory trends (Batiran and Salim, 2020).

Finally, in the current era characterized by ongoing and impending climate-related crises, studying a vast and climate-sensitive archipelago such as Wallacea will provide many learning opportunities. Much research on Indonesia has focused on deforestation, species extinction, carbon loss, carbon mitigation, and the REDD+ scheme. Reorienting research around the Wallacea region can refocus attention to how communities and human-natural systems are adapting to regional changes. 
Although the Wallacea region has much to offer, studying the region in isolation limits research potential. The archipelago is fluid in the way the western parts of Wallacea are connected to networks of power and ecological profiles. Similarly, the Eastern regions of Wallacea blend with Melanesian categorizations of coastal Tanah Papua. We also wish to raise one critical question about the overall terminology we are invoking in proposing studies for a distinctly "Wallacean" region. There is a limitation in raising a regional profile based on a long-deceased naturalist that, in his eagerness to learn about the region, participated in the exploitative colonial apparatus. Conservation during Wallace's time was indelibly linked to the drivers of resource discovery and exploitation (Brockway, 1979). Nevertheless, we are yet to find an alternative, indigenous title that describes this vastly diverse yet interconnected region. Thus, we welcome ideas for reimagining this discourse in the future. We now turn to the three elements we believe are fundamental to any research framework seeking to study the Wallacea region.

\section{The ASLi framework: A three-part heuristic for research in Wallacea}

The framework that emerged from discussion and comparative analysis includes three distinct pillars to guide research specific to the Wallacea region. ${ }^{3}$ These include 1) Adat and adaptive local institutions, 2) the State, and 3) Livelihoods. The acronym from this framework spells ASLi, which also means "original" in Bahasa Indonesia. Whereas the first two pillars consist of institutions, they reflexively interact with the fundamental dimensions of the third pillar (livelihoods) to form a clearer picture of community conservation dimensions (see figure 1).

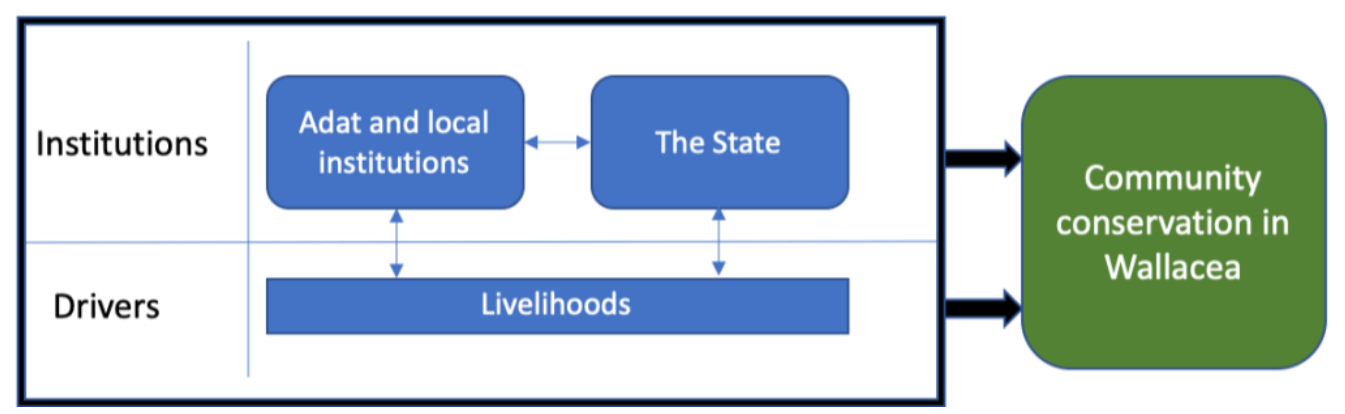

Figure 1. The ASLi Framework for community conservation in Wallacea

These three categories are helpful as part of a larger heuristic, but they are not separate from one another. As this special section clearly shows (Batiran and Salim, 2020; Sirimorok and Asfriyanto, 2020), the notion of adat as indigenous leadership can manifest as local socio-religious rules and ceremony or as part of institutions shaped and defined by colonial policies and the state. Therefore, in some cases adat complements colonial and state driven extensions, and in other cases it invokes positions and authority antithetical to state authority. In addition, livelihood considerations also closely interact with the centers of state power in the region, helping to administer and levy the resource, or as we will also show in the more lucrative illicit natural resource extraction activities, can features the absence of the state (see Setiyani and Ahmad, 2020). These brief examples show that although the heuristic within the parts of the framework are distinct, they fuse and are shaped by their relation to one another.

The ASLi framework serves as a guide for navigating complexity in a particularly diverse underresearched and under-served region. We have also made sure the framework is rooted in inquiries guided by locally based researchers, emerging organically as a way to establish and empower a

\footnotetext{
${ }^{3}$ The framework was also presented, facilitated, and tested for fine tuning during a series of working sessions at the The International Conference of Wildlife Trade and Utilization in the Wallacea Region (IC-WICE) on 22-23 ${ }^{\text {rd }}$ August 2019 in Makassar, South Sulawesi. The conference was supported by Burung Indonesia and hosted by Hasanuddin University, and attended by approximately 250 researchers and practitioners.
} 
network from, and of the region. By introducing the framework, we hope that others will seek to test, challenge, and manipulate it to expand possibilities, sophistication, and the depth of research studying community conservation dynamics in the Wallacea region. It is important to note, however, that categories such as adat and state may change over time. As global ideologies and other forms of identity are contested and reshaped, they give way to new possibilities for the future. Specifically, disruptive technologies can change the boundaries of state and civil society, networks of religion, and what local forms of identity mean during times of migration and mobility. We hope cases in this special section provide examples to direct analytical engagement in research and policymaking settings across the Wallacea region. For now, we believe, that seeing the state and its mechanisms in particular ways in this region, combined with the rich contextual dimensions of adat and local adaptive institutions, as well as the overarching drivers of livelihoods that reflexively interact with these institutions, offers an important set of definitional categories to guide research about, and in Wallacea.

\subsection{Adat and adaptive local institutions}

In proposing the first element of the framework, the most complex challenge for examining this vast and fragmented archipelago relates to the way we define local and regional institutions, particularly those that operate beneath the guise, amidst, or in parallel with formal institutions. This is most prominent in the considerable work about defining adat in Indonesia in recent years (Davidson and Henley, 2007; Muur et al., 2019). In general, adat is a set of rules and identities that are historically formed and expressed, and which is often described as local customs. In addition, adat has also taken on more political meaning as part of its "revivalism" invoked to legitimize local authority. Adat is tied to kinship and ancestry, and often interlinked with religiously defined concepts that take shape in different ways, such as Islam across Sulawesi (Gibson, 2007), Christianity in Toraja and elsewhere (Adams, 1993), and Catholicism in Flores (Erb, 2007). In the past three decades, adat has also powerfully aligned with international movements of indigeneity, finding political space in environmental and social justice movements (Niezen, 2003; Li, 2007; Bettinger et al., 2014), but in its local applications has also become vulnerable to cooptation by powerful interests, in the form of local strongmen making claims to power (van Klinken, 2007) or through interests among formal actors in the processes of recognition (Fisher and van der Muur, 2019). In more recent years however, social movements that coalesced and gained prominence during the fall of the Suharto regime promoted adat as a convening ideology for environmental and social justice in Indonesia. In the post-Suharto political era of decentralization, an NGO described as "the alliance of indigenous peoples of the archipelago" (AMAN) was initially successful in connecting local concerns on land rights issues and inserting such interests among national level political forums. Nevertheless, their vision for adat as a catalyst for a nationwide social movement has stalled because of an inability to translate their political voice to the concerns of larger rural populations (Li, 2020).

Adat in the Wallacea region also has its own distinctions from elsewhere in Indonesia, particularly concerning the revival of customary law associated with conservation, and its relationship to local historical claims of power. For example, in the Maluku and surrounding regions, a revival of customary laws, known as sasi, increasingly articulated an explicit environmental ethos (Zerner, 1994). Zerner's careful account describes the historical origins, revival, reinvention, and expansion of the sasi terminology in local governance, tracking its rediscovery through a reflexive political process taking shape through transnational environmental movements, mobilized by emerging national policy interests, and articulated by local project-based initiatives (see also Lawe, 2000; Thorburn, 2000). Van Klinken (2007) on the other hand, writes about adat in the region as a political tool wielded by those seeking claims to power, revived through inheritance of sultanates reasserting their positions of authority amidst the discourse of adat. This latter association between 
environmental and social justice activists with local strongman politics has made transnational movement proponents uncomfortable, because it challenges the simplified narratives of adat as representing egalitarian environmental stewardship (Ellen, 1986). Though national adat movement leaders acknowledge these problematic contradictions internally, they contend that amidst rapid land consolidation and conversion taking place across Indonesia, the convening power and discourse of adat remains the most effective tool for defending the local against powerful external interests seeking out frontier regions for the purposes of extractive industries or plantation development (Afiff and Rachman, 2019).

The tensions about what adat is and what it represents in Wallacea were on clear display during the formation of this framework. ${ }^{4}$ In the workshops convened for this special section, some authors directly challenged the relevance or importance of adat as a pillar of the framework. These individuals drew from their experiences of adat being wielded locally as a political tool to consolidate power and influence in ways antithetical to what they believed were the goals of community conservation as an ideal rooted in consensus and stewardship. They pointed to examples of how the powers of adat at their research sites were coercive, acting as unjust local institutions, which were dominated by a few powerful elders, almost always men (see also Rye and Kurniawan, 2017; Astuti and MacGregor, 2017 for similar cases from Kalimantan). Conversely, such critical comments about adat came to the surprise of other authors from this special section, who argued that strong local adat institutions are a prerequisite for articulating local environmental values and pursuing conservation goals. Indeed, they pointed to examples of community conservation successes that were indelibly intertwined with local values for governing resources, which is often reflected in the sacred languages that adat extends to the natural world.

A retort from those critical of the adat pillar also questioned its utility on the grounds of future possibility. They asked: "if adat was such an important pillar, how are we to establish adaptive local institutions and governing structures to address new challenges, such as the heightened risks of climate and intensifying interests from coercive outside investors?" These are indeed important considerations and critical questions that should shape future research. For the time being, where we saw common ground across researchers of this special section was in the important role of local institutions. Strong local values and commitment to place underpinned successes in addressing environmental concerns. For the purposes of our framework, we took the middle path in this debate, accepting both arguments in the broader terminology of adat and other adaptive local institutions. If they extend into the realm of local forms of decision-making powers, we believe such a framing needs to be a central component for examining issues of community conservation in the Wallacea region. These critical debates about the definitions and role of adat will continue. We welcome greater engagement to better understand adat in the Wallacea region and engagement with elsewhere in Indonesia, and also hope that discoveries can also help to inform movements of indigeneity and local organizing beyond Indonesia's borders.

This special section provides exemplary work on engaging with and developing a deeper understanding about adat and the formation of local community institutions. Sirimorok and Asfriyanto's research (2020), for example, were guided by an explicitly action-oriented methodology, whereby they worked amidst adat processes and shaped their mode of inquiry around ways to support local interests (see also Fisher et al., 2017). They asked and addressed questions that the community were also eager to learn, and worked with local stakeholders to establish a community and participatory mapping initiative. The outcome was that they gained unusual access, invited to take part as a crucial participant and observer in various negotiations and facilitations, and played an advocacy role with local government and external NGO programs. Building trust in this way also placed them firmly within the local politics of adat rulemaking, and as

\footnotetext{
${ }^{4}$ These discussions took place over three intensive writing workshop sessions in Maros, Sulawesi among a group of the authors in this special section. The workshops took place in April, June, and October, 2019
} 
a result provided tremendous access to information that clearly showed in the depth of their research. On the other hand, Batiran and Salim (2020) took a comparative approach to highlight how different adat institutions can look between one village to the next, whereby one village viewed adat as a longstanding religious practice, and a neighboring village recently established adat rules in conjunction with the arrival of an NGO-funded development and conservation project.

With respect to adat and local adaptive institutions, the lines of power between the formal and informal are unsurprisingly blurred and fluid. This was exemplified in Duncan's (2014) research on ethnic violence in North Maluku, in which the history of violence was described as having ethnic origins, stoked by state backed institutions, that is now viewed mostly through a religious lens. Adat leadership often find themselves claiming powers and authority of, and derived from the state, or other international discourses (Fisher and Muur, 2019). For this reason, we now turn to the second part of our heuristic as a way to explicitly examine the formal authority of the state.

\subsection{The state in Wallacea}

At one point during its history, Wallacea formed the epicenter of many global trade interests, as European-based corporations in the 17th century were eager to claim valuable spices of the region. Though this occurred before the establishment of the modern idea of the nation-state, the eventual tools of the state formed through the influence of distant legal claims and treaties. This early trade history had an indelible influence on the mobility of people, shaping markets and labor opportunity, and the plants that took root among the landscapes. The Sultanate of Tidore for example, highlights its historical influence at the old fort on the island, in the form of a palace and museum. Therein, the artifacts displayed and accompanying narrative presented, describes historical trade relations and transnational treaties that connect the Sultanate's role in the establishment and formation of parts of the Indonesian state.

Indonesia as a state administration however, eventually set up its overall infrastructure far from these fragmented and increasingly remote islands of Wallacea. Having lost its economic primacy, the region became relegated to the frontiers of the state. During the prolonged rule of the Suharto regime and its coercive and extractive practices, the Wallacea region collectively received some of the least attention from the state, making it one of the most neglected and poverty-stricken regions of Indonesia. The attention it did receive was through its role as a state boundary in the Lesser Sundas, exemplified by the fraught conflict of eventual independence from East Timor (see also Batiran and Fisher in this issue on delineating boundaries with the Philippines in the North), and in the potential the overall region held for resource extraction, such as mining.

The fall of Suharto and the introduction of democratic decentralization as state policy at the end of the 20th century did little to refocus attention to the Wallacean region, particularly as the transition also took place amid a financial crisis. The attention Wallacea continues to receive from beyond its borders were often focused on environmental conservation. As demonstrated by the state-facilitated revival of the sasi, NGO and state-led interests sought to protect the region's biodiversity and endemism (Zerner, 1994).

Being relegated to the periphery does not mean that state power is any less. Indeed, distance to certain forms of surveillance and control often yield to more coercive enforcement tactics. It is not uncommon for state authority or bureaucracy to elicit fear and uncertainty among people without personal connections. On the other hand, those that have access to the state also come with the cache and status of extreme privilege for the resources that they can control. In this way, different governing scales also hold different perceptions of the state in the Wallacea region, for example how the state is experienced in a provincial capital versus more remote islands.

Such considerations of historical origins and political developments over time provide important background elements for studying the state in the Wallacea region. Operationalizing questions about how the state is experienced and enacted also revolves around the key actors, 
processes, and mechanisms. Studying the state is perhaps more straightforward than studying adat, since the state is consistently visible in institutions and their authority, including bureaucracy, policies, budgets, and more. For example, examining various elements like local elections, the translation of different policies (like the village law), legal enforcement, and fund disbursements are all sure to reveal a close connection of the state and its political ecologies across varying scales.

\subsection{Livelihoods}

The previous two pillars of our framework "Adat and adaptive local institutions," and "the state," relate to the broader cultural and procedural institutions that shape society, and indeed form critical foundations for our understanding of the regional dynamics of Wallacea. Nevertheless, the main undercurrent that structure people's day-to-day lives are embodied in the third part of our framework, which we label under the broader category of livelihoods. This is not to say that livelihoods are somehow distinct or separate from the state and adat. They no doubt intersect and shape one another. In particular, adat is often intertwined with the conservation of a resource for its direct implications for sustained community livelihoods. The literature on common pool resources suggest that many of the rules for conservation are premised on protecting the longerterm sustainability and access to a resource for local livelihoods. On the other hand, the state also plays a key role in facilitating certain livelihoods and determining access for others. One commonly cited example from across Indonesia is the state enclosures of national forests, that transferred legal management authority of land to the state, making it illegal for people to access land, upon which they had staked their economic futures (Tsing, 2005).

Livelihoods relative to the state are also closely intertwined. Eastern Indonesia is viewed by the central government as a resource frontier, and there are numerous large scale mining, plantation, and fisheries interests. Eastern Indonesia also has low development indicators, a high incidence of poverty, and is also commonly neglected by the state in terms of development resources. This overall background and context for the Wallacea region highlights some of the ways that state policies influence the region and shape the livelihood opportunities available to the people that live there.

Studies of conservation in the region will quickly come across incidents of people traveling further afield to access resources critical for livelihoods. For example, the fisheries literature from the region is replete with destructive practices of blast and cyanide fishing (Thorburn, 2001; Ferse et al., 2010), and although adat rules may be extremely strong, if people need to put food on the table, the terms of their adherence to particular state and adat rules are likely to bend. As a region with high poverty indicators and identified by the state as a resource frontier also likely mean that there will be significant threats to conservation. As extractive and destructive resource practices are widespread, we believe it would be impossible to fully understand community conservation dynamics without a thorough engagement of livelihoods. This is not to suggest that we should blame the poor and vulnerable for negative conservation outcomes, particularly when there are limited options or opportunities to make a living.

\subsection{Methodological dimensions to the ASLi framework}

\subsubsection{Studying the Institutions}

Given that examining adat and adaptive local institutions forces us to examine processes from below, engaging with communities through the appropriate ethical considerations that respond to local concerns are a fundamental prerequisite. There are plenty of resources on such methodological approaches that we do not have space to examine here. Nevertheless, though approaches can take on many forms, we propose a set of guiding questions to better prepare restructure to more systematically think about the key issues they might be looking for as they examine issues of adat and the formation of adaptive local institutions relative to community conservation. Meanwhile, the same line of questioning also applies for examining the formal state 
institutions. For more on the basis of this framing, see also work on common property and property rights (Ostrom, 1990; Schlager and Ostrom, 1994; Rose, 1994), as well as theories of access and exclusion (Ribot and Peluso, 2003; Peluso and Lund, 2009; Hall et al., 2011; Myers and Hansen, 2020). We have modified these frameworks based on our engagement on the Wallacea region, to highlight the following three subheadings that can serve as guiding principles for future research:

1) Actors (Identifying terms of authority): The key positions of authority that individuals or groups take on or are assigned can be found among formal and informal leadership, and particularly among those that claim or are conferred both roles. These include the tasks of decision making that are both explicit and implicit, which occur in various settings. For example, such actors and authority are often clearly visible among local forums for negotiation such as the borong (terminology from areas of Sulawesi) or berougaq (terminology from Sasaks of West Nusa Tenggara, or NTB), which are sites that customary leaders and elders convene for particular decision-making purposes (Fisher 1998; Fisher, 2019). Conversely, although the formal seats of authority are a key consideration, there are also avenues for seeking out the important dimensions about key actors that might be less obvious. This is exemplified by research on matrilocality in which cultural dimensions of gender relations shape political elections that might seem overtly male dominated (Bowie, 2008), but which are more subtly negotiated through the more trusted means of conflict resolution among women's gatherings that are rarely visible or accessible. Such discoveries require a close engagement with how actors negotiate adat and the state, and not surprisingly, identifying the key actors involved in community conservation requires getting close to the resource and identifying the complex dimensions of authority.

2) Power relations (The basis for making decisions): Closely related to an examination of the actors, are also the ways in which institutions come together to make decisions. Complementary to a thorough examination of the actors, also requires a close examination of the various subjectivities among different actors. Beyond the question of who benefits and who gets to decide, are the fundamental explanatory variables about how decisions are made, whether based on class, lineage, gender, age, economic status, and others (Colins and Bilge, 2016).

3) Enactment (How rules are observed, applied, and adhered to): We use the word enactment to signify a constant process of giving actions meaning. In other words, beyond the considerations of who decides, and how decisions are made, is the way in which norms are reinforced. Enactment also stretches our understanding of rule-making into the temporal scale, examining how particular behaviors are established, how resources might otherwise have been allocated and monitored, as well as the adjudication processes and conflict resolution mechanisms that gave shape to certain agreed upon customs. Others have invoked the processual elements of enacting, such as Welker's (2014) examination of the Newmont corporation in NTB. Aside from research taking place across the Wallacea region, the notion of enactment investigates tensions about what makes, sustains, and reinforces adat, adaptive local institutions, and the legitimacy of the state. Taken together, this is about exploring ways of institutions coming into being, a constant revisitation with identity, one that is either longstanding and continually reinforced through certain practices or established in new ways through state politics or transnational social movements.

\subsubsection{Studying Livelihoods}

We would like to define livelihoods as the way people live in a place, which include but are not limited to work and income (Scoones, 2009; Carr, 2015). Dimensions such as traditions, dignity, and knowledge are a fundamental aspect. In particular, our focus is about how livelihoods connects to resources and whether they serve to sustain, protect, improve, or degrade them. It is also important to note that although livelihoods may be about people in place, they are also connected to factors 
that take place far from these places. News about a new commodity and price changes can alter entire landscapes and traditions of work are altered as a result $(\mathrm{Li}, 2014)$. In terms of resources, one effective approach is to study livelihoods by following the "thing" (Cook, 2004), in which all the sites of production and consumption are connected as it is connected to a resource or commodity. In this way we propose an approach to studying livelihoods around the following categories:

1) Production and consumption. This includes questions such as: What/how are people planting and fishing? Is it to grow food, sell surplus, or for cash crops - what seeds, inputs, and land are required? [For marine, what do they need for gas/petrol, nets, poison, bombs, etc]; How have these dynamics changed over time? What types of resources / subsidies (farm equipment, seeds, and agricultural inputs) are available from the state and who benefits from such support? What do beneficiaries do with such support streams?

2) Labor and cultural dimensions of livelihoods: This includes exploring questions such as: What do people do for work and how do they divide their time? For example, many farmers in rural areas rarely describe themselves only as farmers. Are they working for larger regional economic incentive initiatives, are they working as part of local associations (locally driven, or state backed), or are they working as families and individuals? Do they get to decide their options?

3) The cultural dimensions of livelihoods. On an individual level, are they practicing inherited livelihood practices such as hunter or fishers for generations and carrying a family skill or lineage? At a community level, are certain practices of livelihoods tied to local understanding of identity? For example, Asriyani and Verheijen (2020) describe community deer hunting traditions that change relative to the populations of deer, a traditional practice that has declined in the past generation.

\section{The Cases from the Special Section on Community Conservation in the Wallacea Region}

Figure 2 lists the eight cases included in the special section. We assigned a geographic code to each region and provide the corresponding title and contributing author, which is then mapped to the Wallacea region to highlight the location and scale with which the research took place.

\subsection{Communities and species}

Asriyani and Verheijen (2020) analyze the conservation efforts of the small Baar community in co-existing with the Komodo dragons of Riung Subdistrict in Flores. They describe the current dynamics between local adat, state conservation of the Komodo dragon, and the rapid emergence of ecotourism. To understand this complicated relationship, the history of the indigenous Baar tribe foreground the narrative. Livelihood and culture, specifically the hunting rituals of the tribe led to a decline in Komodo dragons on the small peninsula. Since the implementation of the state conservation agenda from the 1980s onwards in the Komodo National Park, the Komodo became a protected species. State conservation rules increasingly dictated the boundaries of where local livelihoods could be pursued, and where hunting rituals could be practiced. This led to a series of conflicts between local communities and conservation agencies. However, through a local adat initiative, in which the local community could formulate new regulations to negotiate with authorities on the new status of the Komodo, a solution was able to emerge to resolve the conflict. This article shows how the Baar were successful in reclaiming initiatives from conservation agencies. The local community formulated new local customary rules on how to treat the Komodo Dragon, hence reclaiming ownership and empowering local institutions. New initiatives are being employed today as the tourism agenda for Eastern Indonesia is being developed. The persisting allure of the Komodo is expected to draw new tourists to the area. 


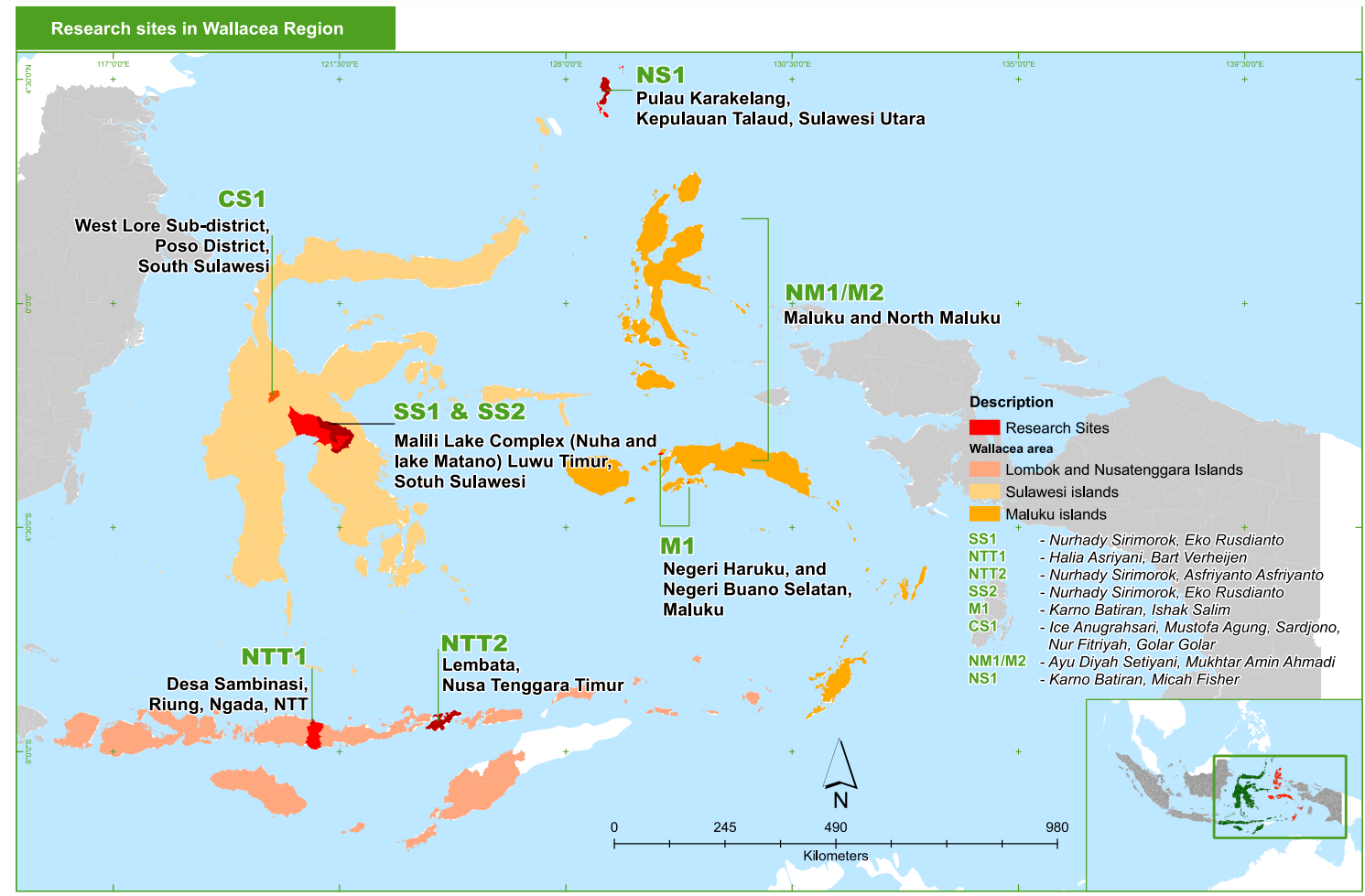

Remark : . Coding: SS (South Sulawesi); NTT (Eastern Nusa Tenggara); M (Maluku); CS (Central Sulawesi); NM (North Maluku); NS (North Sulawesi) - List of sites, authors and titles in the special section

\begin{tabular}{|c|c|c|}
\hline $\begin{array}{l}\text { Map } \\
\text { code }\end{array}$ & Author & Title \\
\hline SS1 & $\begin{array}{l}\text { Nurhady Sirimorok, Eko } \\
\text { Rusdianto }\end{array}$ & $\begin{array}{l}\text { The Importance of Being Political: Emergence of a Multi-stakeholder Forum at the Lake } \\
\text { Malili Complex, South Sulawesi }\end{array}$ \\
\hline NTT1 & $\begin{array}{l}\text { Halia Asriyani, Bart } \\
\text { Verheijen }\end{array}$ & $\begin{array}{l}\text { Protecting the Mbau Komodo in Riung, Flores: Local Adat, National Conservation and } \\
\text { Ecotourism Developments }\end{array}$ \\
\hline NTT2 & $\begin{array}{l}\text { Nurhady Sirimorok, } \\
\text { Asfriyanto Asfriyanto }\end{array}$ & $\begin{array}{l}\text { The return of the muro: Institutional bricolage, customary institutions, and protection of } \\
\text { the commons in Lembata Island, Nusa Tenggara }\end{array}$ \\
\hline SS2 & $\begin{array}{l}\text { Nurhady Sirimorok, Eko } \\
\text { Rusdianto }\end{array}$ & $\begin{array}{l}\text { Conditions for Success in a Community Based Conservation Initiative: An Analysis of } \\
\text { Triggering Moments and Catalytic Elements in Nuha }\end{array}$ \\
\hline M1 & $\begin{array}{l}\text { Karno Batiran, Ishak } \\
\text { Salim }\end{array}$ & $\begin{array}{l}\text { A Tale of Two Kewangs: A comparative study of traditional institutions and their effect on } \\
\text { conservation in Maluku }\end{array}$ \\
\hline CS1 & $\begin{array}{l}\text { Ice Anugrahsari, Mustofa } \\
\text { Agung Sardjono, Nur } \\
\text { Fitriyah, Golar Golar }\end{array}$ & $\begin{array}{l}\text { Social Contracts: Pillars of Community Conservation Partnerships in Lore Lindu National } \\
\text { Park, Indonesia }\end{array}$ \\
\hline $\begin{array}{l}\text { NM1 } \\
\text { /M2 }\end{array}$ & $\begin{array}{l}\text { Ayu Diyah Setiyani, } \\
\text { Mukhtar Amin Ahmadi }\end{array}$ & An overview of illegal parrot trade in Maluku and North Maluku Provinces \\
\hline NS1 & $\begin{array}{l}\text { Karno Batiran, Micah } \\
\text { Fisher }\end{array}$ & From Hunter to Protector: The Invention and Reinvention of the Nuri Talaud \\
\hline
\end{tabular}

Figure 3. Research sites in the Wallacea region.

At the Northernmost reaches of the Indonesian state, Batiran and Fisher (2020) similarly describe a case involving a single charismatic species. In this case, the Nuri Talaud, a small endemic and critically endangered lorry undergoes a series of changes from near extinction to revival. Though 
ignored prior to the 1980s, the Nuri Talaud first gained recognition as a unique species for its colorful appearance and due to its geographic location at the boundaries of the state. This led to it being showcased in the national museum of Indonesian culture and diversity in the state capital. Though its placement at such a significant site intended to showcase a national treasure, it also sparked economic demand for the capture and sale of the bird through illegal transnational trade markets. Batiran and Fisher's narrative describes a process of transformation, during which the hunters became the bird's protectors. Several initiatives involving international researchers, NGO support, and local student and community organizations came together to shape a new identity for the bird. Closely involving local hunters and paying particular attention to the changing livelihood dynamics demonstrates how a species can change from a symbol of livelihood to be extracted to a valued resource to be treasured and protected.

Setiyani and Ahmadi (2020) present a timely case study by examining an understudied and complex phenomenon, namely law enforcement on illicit trade networks of bird species. Examining data at various scales, they present exactly which types of being species are being sold, where the sales are taking place, and how the networks evade law enforcement. Though the origins of the cases are about endemic species from the Malukus, they effectively present a narrative of how transnational species trade is shaped by drivers from beyond the region, incorporating intermediaries, regional hubs, and international buyers. In this way the show how the practice continues to persist by describing the factors that allow it to continue, the practices that transport the birds and evade authorities, which also lead to high levels of mortality. The research also concludes with various intervention priorities that authorities can do to work with communities at the source as well as how authorities can more effectively reduce incentives on both the supply and demand dimensions of this trade.

\subsection{Conservation and institutions}

The next five articles shift from focusing on the relationship between people and specific species to institutional considerations across the broad spectrum of conservation and development. In Lembata NTT, Sirimorok and Asfriyanto describe the evolving cultural system of the muro, an intricate set of rules that regulates, sanctions, adjudicates and determines resource use. The rules address anything from specifying locations of land and marine area uses, the type of cultivation practices or equipment used at those locations, and the timing of certain practices. The authors describe the muro and the changes it underwent over time, hibernating for decades during the New Order era only to re-emerge in more forceful ways during the reform era of democratic decentralization. The research also involved actively attending and participating in local meetings during establishment of a new muro. To contextualize muro changes over time, three different cases are presented. The first involves a muro on wildland and forest burning rapidly transforming landscapes, while the second describes a case of addressing extractive fishing industry practices. The third, and process they were able to witness, examined a muro to extend the area of marine protection. In this process they show how the authority of establishing muro are interpreted, accepted, and revived within formal institutional governing systems.

Batiran and Salim (2020) expand the focus to compare traditional natural resource institutions in two nearby villages in Maluku. Using an approach of historically-situated new institutionalism, they describe how cultural rules (kewang) on natural resources were shaped over time across the region and highlight how one village maintained longstanding kewang, whereas a nearby village that long abandoned their kewang recently revived the practice through the facilitation of an outside NGO. They explore the differences between the kewang, their current legitimacy and practices, focusing on how historical incidences of conflict, resistance, triumph, and acquiescence are fundamental for understanding the capacity and capabilities of institutions responsible for conservation. They also begin to point to the important scalar dimensions of conservation institutions, in which one village to the next view cultural practices in contradictory ways. 
The article by Sirimorok and Rusdianto (2020a) takes on directly the issue of governing scales at the village and district levels. They examine the opportunities for developing conservationoriented coalitions based on replicating successful localized cases. Situated in a setting of extractive land use practices and tightly controlled water regulations, combined with vulnerable ecosystems and degraded environments, significant efforts have sought to develop ways to more sustainably manage natural resources by convening stakeholders of mutual concern. The analysis focused on one village that gained significant traction, garnering attention as a model for scaling up multistakeholder collaboration. As much attention as the initiative received however, they were unable to make inroads among powerful and vested interests at the district level. Zeroing in on what the authors describe as the "importance of being political," they convincingly argue for fundamental preconditions in working with communities and other stakeholders on conservation. This case especially highlights challenges from across the Wallacea region and the key issues that need to be addressed when scaling up more localized initiatives.

Anugrahsari et al. (2020) take us to a different setting, namely into the conditions of people living and seeking out livelihoods within areas enclosed under the jurisdiction of a national park. They describe conditions where over 100,000 people are living amidst and interacting with the Lore Lindu National Park in Central Sulawesi. The dynamics involve both local indigenous populations and migrants, as well as the overall pressures on land use and livelihood taking place there. Approaching their research in the tradition of collaborative management of natural resources, they track the establishment of community conservation agreements that have taken place over the past two decades in the Park. Overall the findings point to the imbalance of power and the inattentiveness to process, which have resulted in the repeated failures of workable agreements between park managers and local communities. This is also despite the engagement of international institutions and well-funded donor projects that sought to facilitate the process.

A second contribution by Sirimorok and Rusdianto (2020b) takes us to the conceptual dimensions of community conservation arrangements by asking the provocative question of what conditions determine whether community conservation will succeed. They apply a common framework from the literature on the commons and downscale it to a specific case in Nuha, South Sulawesi. The findings point to the rich potential of theoretical contributions that are possible from Wallacea, as they point out that common frameworks are able to determine the pillars that determine success. Nevertheless, they also show that there is no substitute to the rich historical and political ecological work in studying people and places, which common conservation frameworks might overlook.

\section{Emerging issues on community conservation in Wallacea}

This special section draws from eight original articles and is also part of a broader research engagement, in which editors of Forest and Society seek to promote research and collaboration in under-represented regions in Southeast Asia. This special section showcases some of the most extensive research in an international journal on environmental issues in the Wallacea region. Based on the contributions to this special section and the series of workshops in which local researchers discussed these issues, we offer four conclusions.

First, there is a lack of research about and from the Wallacea region. This dearth of research must be addressed in order to cultivate a foundation for serious engagement and sustained scholarship. We have high hopes that the ASLi framework presented here can guide future research and establish an ongoing research agenda. Regardless, sustained research, approached with depth and rigor, that also supports the capacity and continued engagement of locally-based researchers and institutions, will help advance better understanding of perplexing and often contradictory human-natural dynamics unfolding in Wallacea. 
Second, there exists a sustained interest in conservation partnerships, through state or nonstate actors. From a policy standpoint, the Indonesian government recognizes land rights and the role of rural communities to land and forests (Fisher et al., 2019; Erbaugh, 2019). Such recognition is not limited to formal government efforts, but also includes NGO-community conservation partnerships as well as various international organizations that support communities for their role in conservation. State-supported initiatives are taking shape across three broad policy initiatives, including agrarian reform, social forestry, and adat, which are being interpreted and implemented in particular ways in the Wallacea region. Such initiatives require close scrutiny among the research community in order to track implementation, examine the limits and possibilities, as well as supporting potential discoveries for new innovations. Research from Maluku, for example, (Salampessy et al., 2017), highlights the flaws of social forestry policy applications for its overly formulaic solutions, as middlemen co-opted the process that led to the dispossession of forest cultivators to their groves of cloves. A number of the contributions to this special section also seek to explore these and other formally supported community-based or co-management arrangements, ranging from a close examination of local institutions and their practices related to conservation (Batiran and Salim, 2020; Sirimorok and Safriyanto, 2020b), or more explicit community conservation partnerships initiated and supported by the state and other partners to develop new models for managing forest and coastal/marine areas (Anugrahsari et al., 2020; Sirimorok and Rusdianto, 2020a; Sirimorok and Rusdianto, 2020b). Nevertheless, there is much more to be explored among these and other policy prescriptions for involving communities in conservation from across this vast region.

The third conclusion emerges from the much less research available on development trajectories in the Wallacea region. Though this special section focused on areas that can teach us about community and conservation, these concerns are closely intertwined with the underlying political economic dynamics influencing environment and development more broadly. For example, from across Southeast Asia the global land rush has served to create new forms of land, state, and community relations (Hall et al., 2011). Literature on land use change specific to Indonesia has focused largely on palm oil expansion in Sumatra and Kalimantan (Cramb and McCarthy, 2009). Similar expansion efforts are evident in Wallacea, and though much less understood, mining, oil palm, and other plantation crops have spread at a heightened pace in recent years. As development projects map out new possibilities into these frontier regions, they are sure to build on existing ventures and networks of possibility, such as in the form of blue and green development (Wright, 2017; Fairhead et al., 2012; McCarthy and Thatcher, 2017) or the expansion of more extractive networks of mining and deep-sea economic ventures (Erb, 2016). McCarthy et al.'s (2012) piece is poignant in this light, where virtual territorialization tests out sites for land grabbing through the promotion of green commodities like the trials of Jatropha plantations that began to take root in Sumba, NTT province. In this case, though the projects fail to materialize, they do push the boundaries of possibility and serve as precursors for moving along subsequent proposed projects, meanwhile serving to extend capital through the state development apparatus to otherwise inaccessible regions.

Alongside these larger scale development considerations are also the welfare and development policies of the Indonesian state, which have most popularly been articulated through the block grant mechanisms inherent in the 2014 Village Law (Vel and Bedner, 2015). As the fund transfers begin to operate more regularly and extensively, the way that implementation unfolds will have an indelible impact on communities and the environment. Almost all articles from this special section mentioned the influence of the Village Law on local institutions. For now, the largest fund allocations are devoted to infrastructure, particularly for road building, which is an underlying but rarely acknowledged factor of environmental impacts across Indonesia. How and where these roads are built are sure to have exponential impacts as they are replicated and applied across all villages across the Wallacea region. 
One surprising set of contributions in this special section examines illicit international trade networks for species. Two of the contributions focused on trade of parrots, parakeets, and lorries and described just how extensive these trade networks are (Batiran and Fisher, 2020; Setiyani and Ahmadi, 2020). Across these articles, we can observe the extent of these networks, rooted in Wallacea but traveling well beyond its boundaries. Such economic opportunities are commonly accepted locally as a viable and lucrative livelihoods alternative, but all the articles herein describe the overall identity formulations relative to the species, that either allow and encourage exploitation, or explicitly defend against it. Therefore, it is not only that we need to better understand these processes, but the articles also describe the importance of engaging with communities to better understand the role of species in nature, before they are forever lost.

The question of conservation has also shifted to alternative economic development opportunities for supporting conservation. The charismatic Komodo (Asriyani and Verheijen, 2020) and the vast proliferation of eco-tourism across Wallacea points to a new emerging trend to showcase the diverse culture of the region alongside exotic natural land and seascapes in their habitat. This has indeed led to significant investment in new economic opportunities that are more concerned with conservation. However, the policies, projects, and applications of eco-tourism also require closer scrutiny to also examine just who benefits and loses.

\section{Conclusions: Future horizons for research}

In this introduction to the special section for community conservation in the Wallacea region we have made a strong case for an explicit regional and area studies agenda for Wallacea. As an under-represented and overlooked region, we have shown its importance based on its geographical extent and uniqueness, the large and diverse populations dispersed across the region, its historical place in society and the contemporary development considerations specific to the region, and its terrestrial, avian, and marine endemism. Wallacea is often mistakenly blurred into studies about Indonesia or completely overlooked.

We have set out to develop a framework for the future study of the region, particularly those interested in issues of community and conservation. Based on our engagement with the region and the contributions to this special section, our ASLi framework incorporates (i) bottom up dynamics of adat and adaptive local institutions, combined with (ii) the more formalized and often top-down implementation of policies of the state and international regimes, and (iii) propose contextualizing them within explicit engagement on livelihoods. Together, these three elements provide an approach for researchers to examine more broadly the issues of environment and development specific to the region. The framework is particularly useful for those that seek to examine community dynamics, the implementation of policies, and can be applied to past research in the region or in the formulation of new research initiatives. The framework is not designed to provide equal weight to each part of the framework, nor do we feel it should be limited to just the three broadly proposed categories. Nevertheless, it provides a useful starting place and key guiding questions to help researchers get started and move along the analytical process, markers for pointing out areas that should not be overlooked.

Finally, the special section also established a rich foundation of empirical research on the Wallacea region. We have come to some firm conclusions about current trends, and also presented a broad set of areas that require further exploration. Meanwhile, there are also sure to be dynamics that we have not addressed. For example, a changing climate, the vulnerabilities, and adaptations experienced in small island contexts can yield interesting findings to recalibrate preconceptions about the status quo. For now, however, we hope that this set of contributions does present a baseline that leads to sustained research that supports the knowledge and capacity of those of the region, and those interested in learning more about the region. 


\section{Acknowledgements}

We would like to thank the reviewers that provided substantial inputs for making this paper and special section possible. We also thank the programs and projects spearheaded by Universitas Hasanuddin, Birdlife International and local partners Burung Indonesia and their collaboration to support the workshops, researchers, editors, and fieldwork. Thanks to Perkumpulan Payo-Payo for their commitment to work closely with communities and the series of workshops they put together to bring this special section together. Foremost, we would like to acknowledge the participation and involvement of all the local voices from the field sites that provided great depth to all the empirical work throughout the special section.

\section{Conflicts of interest}

The authors declare no conflict of interest.

\section{References}

Adams, K. M. (1993). The discourse of souls in Tana Toraja (Indonesia): indigenous notions and Christian conceptions. Ethnology, 32(1), 55-68. doi: http://dx.doi.org/10.2307/3773545

Anugrahsari, I., Sardjono, M., Fitriyah, N., \& Golar, G. (2020). Social Contracts: Pillars of Community Conservation Partnerships in Lore Lindu National Park, Indonesia. Forest and Society, 4(1), 115-126. doi: http://dx.doi.org/10.24259/fs.v4i1.8682

Ardhana, I.K. (2005). Penataan Nusa Tenggara pada Masa Kolonial 1915-1950. Jakarta: PT RadjaGrafindo Persada,

Asriyani, H., \& Verheijen, B. (2020). Protecting the Mbau Komodo in Riung, Flores. Local Adat, National Conservation and Ecotourism Developments. Forest and Society, 4(1), 20-34. doi:http://dx.doi.org/10.24259/fs.v4i1.7465

Afiff, S. A., \& Rachman, N. F. (2019). Institutional Activism: Seeking Customary Forest Rights Recognition from Within the Indonesian State. The Asia Pacific Journal of Anthropology, 20(5), 453-470. doi: https://doi.org/10.1080/14442213.2019.1670245

Armitage, D. R., Plummer, R., Berkes, F., Arthur, R. I., Charles, A. T., Davidson-Hunt, I. J., ... \& McConney, P. (2009). Adaptive co-management for social-ecological complexity. Frontiers in Ecology and the Environment, 7(2), 95-102. doi: https://doi.org/10.1890/070089

Astuti, R., \& McGregor, A. (2017). Indigenous land claims or green grabs? Inclusions and exclusions within forest carbon politics in Indonesia. The Journal of Peasant Studies, 44(2), 445-466. doi: https://doi.org/10.1080/03066150.2016.1197908

Batiran, K., \& Fisher, M. (2020). From Hunter to Protector: The Invention and Reinvention of the Nuri Talaud. Forest and Society, 4(1), 1-13. doi:http://dx.doi.org/10.24259/fs.v4i1.7438

Berkes, F. (1999). Sacred ecology: traditional ecological knowledge and resource management Taylor and Francis. London Science and the St Elias, 203.

Bettinger, K., Fisher, M., \& Miles, W. (2014). The art of contestation and legitimacy: environment, customary communities, and activism in Indonesia. Occupy the Earth: Global Environmental Movements Advances in Sustainability and Environmental Justice, vol. 15.

Bowie, K. (2008). Standing in the shadows: Of matrilocality and the role of women in a village election in northern Thailand. American Ethnologist, 35(1), 136-153. doi: https://doi.org/10.1111/j.1548-1425.2008.00010.x

Brockway, L. H. (1979). Science and colonial expansion: the role of the British Royal Botanic Gardens. American Ethnologist, 6(3), 449-465. doi: https://doi.org/10.1525/ae.1979.6.3.02a00030

Brosius, J. P., Tsing, A. L., \& Zerner, C. (1998). Representing communities: Histories and politics of community-based natural resource management. doi: https://doi.org/10.1080/08941929809381069

Carr, E. R. (2015). Political ecology and livelihoods. Handbook of political ecology, 332-342.

Collins, P. H., \& Bilge, S. (2016). Intersectionality. John Wiley \& Sons. 
Cook, I. (2004). Follow the thing: Papaya. Antipode, 36(4), 642-664. doi: https://doi.org/10.1111/j.1467-8330.2004.00441.x

Cronon, W. (2009). Nature's metropolis: Chicago and the Great West. WW Norton \& Company.

Davidson, J., \& Henley, D. (Eds.). (2007). The revival of tradition in Indonesian politics: The deployment of adat from colonialism to indigenism. Routledge.

Duncan, C. R. (2014). Violence and vengeance: Religious conflict and its aftermath in eastern Indonesia. NUS Press.

Ellen, R. F. (1986). What Black Elk left unsaid: on the illusory images of Green primitivism. Anthropology Today, 2(6), 8-12. doi: https://doi.org/10.2307/3032837

Emerson, R. M., Fretz, R. I., \& Shaw, L. L. (2011). Writing ethnographic fieldnotes. University of Chicago Press.

Erb, M. (2007). Adat revivalism in western Flores. The revival of tradition in Indonesian politics: The deployment of adat from colonialism to indigenism, 5, 247. Routledge

Erb, M. (2016). Mining and the conflict over values in Nusa Tenggara Timur Province, Eastern Indonesia. The Extractive Industries and Society, 3(2), 370-382. doi: https://doi.org/10.1016/j.exis.2016.03.003

Erbaugh, J. T. (2019). Responsibilization and social forestry in Indonesia. Forest Policy and Economics 109, 102019. doi: https://doi.org/10.1016/j.forpol.2019.102019

Fairhead, J., Leach, M., \& Scoones, I. (2012). Green grabbing: a new appropriation of nature?. Journal of peasant studies, 39(2), 237-261. doi: https://doi.org/10.1080/03066150.2012.671770

Ferse, S. C., Costa, M. M., Manez, K. S., Adhuri, D. S., \& Glaser, M. (2010). Allies, not aliens: increasing the role of local communities in marine protected area implementation. Environmental Conservation, 37(1), 23-34. doi: https://doi.org/10.1017/S0376892910000172

Fisher, Lawrence A. (1999). Beyond the Berugaq: Conflict, Policy and Decision-making in Forest and Conservation Management in Nusa Tenggara, Indonesia. Cornell University.

Fisher, M. R. (2019). Beyond Recognition: Indigenous Land Rights and Changing Landscapes in Indonesia (Doctoral dissertation, University of Hawai'i at Manoa).

Fisher, M. R., Dhiaulhaq, A., \& Sahide, M. A. K. (2019). The politics, economies, and ecologies of Indonesia's third generation of social forestry: An introduction to the special section. Forest and Society, 3(1), 152-170. doi: http://dx.doi.org/10.24259/fs.v3i1.6348

Fisher, M. R., Moeliono, M., Mulyana, A., Yuliani, E. L., Adriadi, A., Judda, J., \& Sahide, M. A. K. (2018). Assessing the new social forestry project in Indonesia: recognition, livelihood and conservation?. International Forestry Review, 20(3), 346-361. doi: https://doi.org/10.1505/146554818824063014

Fisher, M. R., \& van der Muur, W. (2020). Misleading Icons of Communal Lands in Indonesia: Implications of Adat Forest Recognition From a Model Site in Kajang, Sulawesi. The Asia Pacific Journal of Anthropology, 21(1), 55-76. doi: https://doi.org/10.1080/14442213.2019.1670244

Fisher, M. R., Workman, T., Mulyana, A., Institute, B., Moeliono, M., Yuliani, E. L., ... \& Adam, U. E. F. B. (2017). Striving for PAR excellence in land use planning: Multi-stakeholder collaboration on customary forest recognition in Bulukumba, South Sulawesi. Land Use Policy. doi: https://doi.org/10.1016/j.landusepol.2017.09.057

Gibson, T. (2007). Islamic narrative and authority in Southeast Asia: from the 16th to the 21st century. Springer.

Hall, D., Hirsch, P., \& Li, T. M. (2011). Powers of Exclusion: Land Dilemmas in Southeast Asia. Honolulu: University of Hawai'i Press

Lake, R. W. (2002). Bring back big government. International Journal of Urban and Regional Research, 26(4), 815-822. doi: https://doi.org/10.1111/1468-2427.00420

Li, T. M. (2020). Epilogue: Customary Land Rights and Politics, 25 Years On. The Asia Pacific Journal of Anthropology, 21(1), 77-84. doi: https://doi.org/10.1080/14442213.2020.1680016 
Li, T. M. (2007). The will to improve: Governmentality, development, and the practice of politics. Duke University Press.

Lowe, C. (2000). Global markets, local injustice in Southeast Asian seas: the live fish trade and local fishers in the Togean Islands of Sulawesi. People, plants, and justice: the politics of nature conservation. Columbia University Press, New York, New York, USA, 234-258.

McCarthy, J., \& Thatcher, J. (2019). Visualizing new political ecologies: A critical data studies analysis of the World Bank's renewable energy resource mapping initiative. Geoforum, 102, 242-254. doi: https://doi.org/10.1016/j.geoforum.2017.03.025

McCarthy, J. F., Vel, J. A., \& Afiff, S. (2012). Trajectories of land acquisition and enclosure: development schemes, virtual land grabs, and green acquisitions in Indonesia's Outer Islands. Journal of Peasant Studies, 39(2), 521-549. doi: https://doi.org/10.1080/03066150.2012.671768

McCarthy, J. F., \& Cramb, R. A. (2009). Policy narratives, landholder engagement, and oil palm expansion on the Malaysian and Indonesian frontiers. Geographical Journal, 175(2), 112-123. doi: https://doi.org/10.1111/j.1475-4959.2009.00322.x

van der Muur, W., Vel, J., Fisher, M. R., \& Robinson, K. (2019)). Changing Indigeneity Politics in Indonesia: From Revival to Projects. doi: https://doi.org/10.1080/14442213.2019.1669520

Myers, R., \& Hansen, C. P. (2020). Revisiting a theory of access: a review. Society \& Natural Resources, 33(2), 146-166. doi: https://doi.org/10.1080/08941920.2018.1560522

Niezen, R. (2003). The origins of indigenism: Human rights and the politics of identity. Univ of California Press.

Ostrom, E. (1990). Governing the Commons: The Evolution of Institutions for Collective Action. Cambridge University Press.

Resosudarmo, B. P., \& Jotzo, F. (Eds.). (2009). Working with nature against poverty: Development, resources and the environment in eastern Indonesia. Institute of Southeast Asian Studies.

Ribot, J. C., \& Larson, A. M. (Eds.). (2013). Democratic decentralisation through a natural resource lens: cases from Africa, Asia and Latin America. Routledge.

Ribot, J. C., \& Peluso, N. L. (2003). A theory of access. Rural sociology, 68(2), 153-181. doi: https://doi.org/10.1111/j.1549-0831.2003.tb00133.x

Robbins, P. (2011). Political ecology: A critical introduction (Vol. 16). John Wiley \& Sons.

Rose, C. M. (2019). Property and persuasion: Essays on the history, theory, and rhetoric of ownership. Routledge. doi: https://doi.org/10.4324/9780429303227

Rye, S. A., \& Kurniawan, N. I. (2017). Claiming indigenous rights through participatory mapping and the making of citizenship. Political Geography, 61, 148-159. doi: https://doi.org/10.1016/j.polgeo.2017.08.008

Salampessy, M. L., Febryano, I. G., \& Zulfiani, D. (2017). Bound by debt: Nutmeg trees and changing relations between farmers and agents in a Moluccan agroforestry systems. Forest and Society, 1, 137-143. doi: http://dx.doi.org/10.24259/fs.v1i2.1718

Scoones, I. (2009). Livelihoods perspectives and rural development. The journal of peasant studies, 36(1), 171-196. doi: https://doi.org/10.1080/03066150902820503

Setiyani, A., \& Ahmadi, M. (2020). An overview of illegal parrot trade in Maluku and North Maluku Provinces. Forest and Society, 4(1), 48-60. doi:http://dx.doi.org/10.24259/fs.v4i1.7316

Schapper, A. (2015). Wallacea, a linguistic area. Archipel. Études interdisciplinaires sur le monde insulindien, (90), 99-151.

Schlager, E., \& Ostrom, E. (1992). Property-rights regimes and natural resources: a conceptual analysis. Land economics, 249-262. doi: http://dx.doi.org/10.2307/3146375

Sikor, T., \& Lund, C. (Eds.). (2010). The politics of possession: Property, authority, and access to natural resources. John Wiley \& Sons. 
Sirimorok, N., \& Asfriyanto, A. (2020). The return of the muro: Institutional bricolage, customary institutions, and protection of the commons in Lembata Island, Nusa Tenggara. Forest and Society, 4(1), 61-80. doi: http://dx.doi.org/10.24259/fs.v4i1.7676

Sirimorok, N., \& Rusdianto, E. (2020a). The Importance of Being Political: Emergence of a Multistakeholder Forum at the Lake Malili Complex, South Sulawesi. Forest and Society, 4(1), 98114. doi: http://dx.doi.org/10.24259/fs.v4i1.7442

Sirimorok, N., Rusdianto, N. (2020b). Why a Community Based Conservation Initiative Succeeds? An Analysis of Triggering Moments and Catalytic Elements in Nuha. Forest and Society, 4(1), 127141. doi: http://dx.doi.org/10.24259/fs.v4i1.8184

Thorburn, C. (2001). The house that poison built: customary marine property rights and the live food fish trade in the Kei Islands, Southeast Maluku. Development and Change, 32(1), 151-180. doi: https://doi.org/10.1111/1467-7660.00200

Thorburn, C. C. (2000). Changing customary marine resource management practice and institutions: the case of Sasi Lola in the Kei Islands, Indonesia. World Development, 28(8), 1461-1479. doi: https://doi.org/10.1016/S0305-750X(00)00039-5

Tsing, AL (2005). Friction: An ethnography of global connection. Princeton University Press.

Van Klinken, G. (2007). Return of the sultans: the communitarian turn in local politics. In The Revival of Tradition in Indonesian Politics (pp. 169-189). Routledge.

Vel, J. A., \& Bedner, A. W. (2015). Decentralisation and village governance in Indonesia: the return to the nagari and the 2014 Village Law. The Journal of Legal Pluralism and Unofficial Law, 47(3), 493-507. doi: https://doi.org/10.1080/07329113.2015.1109379

Wallace, A. R. (1962). The Malay Archipelago: the land of the orang-utan and the bird of paradise; a narrative of travel, with studies of man and nature. Courier Corporation.

Wall, V.I van der. (1928). De Nederlandsche Oudheden in de Molukken. S'Gravenhage: Martinus Nijhoff,

Welker, M. (2014). Enacting the corporation: an American mining firm in post-authoritarian Indonesia. Univ of California Press.

Wright, E. C. (2017). The Upshot Of Upgrading: Seaweed Farming And Value Chain Development In Indonesia (Doctoral dissertation, University of Hawai'i at Mānoa).

Zerner, C. (1994). Through a green lens: The construction of customary environmental law and community in Indonesia's Maluku Islands. Law and society review, 1079-1122. doi: http://dx.doi.org.10.2307/3054024 